\title{
Unfolding the secrets of plum pox virus: from epidemiology to genomics
}

\author{
Z. ŠUBR, M. GLASA
}

Institute of Virology, Slovak Academy of Sciences, Dúbravská cesta 9, 84505 Bratislava, Slovak Republic

\begin{abstract}
Summary. - Over an approximately 80 -year period since the description of the Sharka disease, the plum pox virus (PPV) has been thoroughly studied on various levels of the infection cycle. World-wide distribution of the virus, severity of the disease for the fruit industry with a potential to be further increased and discovery/ emergence of new strains make PPV the most epidemiologically important viral pathogen of stone fruit trees. The history of PPV research reflects the development of analytical methods applicable in plant virology. In particular the establishment of molecular biology with reverse genetics and improvement of DNA sequencing technology have further contributed to the increase in knowledge on PPV variability, evolution, replication and interaction with host plants. This review gives a comprehensive summary of PPV data accumulated progressively, from the biological characterization of the disease to recent attempts aimed at using the PPV-based vectors for expression of exogenous proteins in plants.
\end{abstract}

Keywords: Sharka; variability; diagnostics; genome sequence; infectious clone

\section{Contents:}

1. Introduction

2. PPV strain variability

3. Diagnostics

4. Epidemiological aspects of PPV infections

5. Expression strategy and non-structural proteins

6. Capsid protein

7. Infectious clones and PPV-based expression vectors

8. Conclusion

\section{Introduction}

Sharka disease of stone fruit trees was observed in Bulgaria around WW1 and shortly after, its viral origin was also reported (Atanasoff, 1935). The agent causing this disease is plum pox virus (PPV) from the family Potyviridae (the genus Potyvirus). PPV natural host range comprises the genus Prunus including commercial stone-fruit crops, as

E-mail: virusubr@savba.sk; phone: +421-2-59302447.

Abbreviations: $\mathrm{CP}=$ capsid protein; $\mathrm{MAb}(\mathrm{s})=$ monoclonal antibody(ies); PPV = plum pox virus; PTGS = posttranscriptional gene silencing; $\mathrm{PVA}=$ potato virus $\mathrm{A} ; \mathrm{RFLP}=$ restriction fragments length polymorphism well as wild and ornamental species. Nowadays PPV is widespread almost globally, being detected in all continents apart from Australia (García and Cambra, 2007). Sharka is an economically important disease, potentially leading to high crop losses. Just one or few infection foci in the individual tree canopy in the early stage of the disease may be simply overlooked by visual inspection, however the infected tree is incurable and symptoms can deteriorate with time. Leaf symptoms include dark-light spots, rings and mosaics of various shapes and intensity, chlorosis or leaf deformation. The impact on the fruits of the susceptible genotypes, particularly in later stages of disease may be drastic - from deformation, discoloration and lowered sugar content to enhanced premature downfall (Milosevic et al., 2010). PPV as an object of extensive epidemiological and molecular research is one of the best studied potyviruses (Scholthof et al., 2011).

\section{PPV strain variability}

Intensive accumulation of sequence data in recent years has provided a detailed overview of PPV genetic diversity and evolution. Several strains of PPV have been discovered, all genetically distinctive with serological particularities and biological properties including natural host range, relative 
infectivity and symptomatology in natural and artificial host species. The first two PPV strains have been described as serotypes PPV-D and PPV-M showing different reactivity with antibodies in immunodiffusion tests (Kerlan and Dunez, 1979). As these serotypes were found to be vastly prevalent in Europe, PPV variability has been considered to be very low for a long time (Revers et al., 1996). While the PPV-D isolates have been found mainly in plums and apricots (Dallot et al., 1998), PPV-M has been linked to the severe epidemics of peaches (Pasquini and Barba, 1997), leading to a narrowing generalization of the strain properties.

Molecular analysis of the Egyptian isolate El Amar classified it to a different strain (PPV-EA; Wetzel et al., 1991b). The isolate was initially recovered from apricot in a geographically restricted region of northern Africa. Complete sequencing of two subisolates of the original El Amar isolate differing in the number of mechanical passages in Nicotiana host showed a high potential for molecular changes of PPV genome under artificial conditions (Glasa et al., 2006; Myrta et al., 2006). Recently, a relatively high genetic diversity of PPV-EA isolates has been demonstrated in Egypt and the authors have suggested that this strain has not resulted from a recent introduction of PPV to Africa (Matic et al., 2011).

The strain PPV-C comprises initially the isolates SoC and SwC (found on sour and sweet cherry, respectively) from Moldova and Italy (Kalashyan et al., 1994; Crescenzi et al., 1995). The isolates capable of naturally infecting cherries were later sporadically found in some other European countries also (Nemchinov et al., 1998; Malinowski et al., 2012; Kajic et al., 2012), however, no economic impact on the cherry industry has been recorded. PPV-C showed high genome sequence divergence with sequences of PPV-M, D and EA in several nonstructural genes and in the region coding for N-terminal capsid protein (CP) domain (Fanigliulo et al., 2003). Although PPV-C was isolated exclusively from cherry trees, it has also been shown under experimental conditions to be capable of systematically infecting plum rootstocks after chip inoculation (Bodin et al., 2003).

Four PPV strains in total had been discovered by the end of the last millennium, two of which were geographically (PPV-EA) or host (PPV-C) restricted (Pasquini and Barba, 1997). The image of PPV variability dramatically changed in the years that followed. Although the first report of a recombinant PPV was published in 1993, it was considered as curious or artificial isolate resembling PPV-M by the 3 '-proximal and PPV-D by the 5 ' -proximal part of genome (Cervera et al., 1993). Later, a number of isolates with the same recombination point in the NIb gene (see Expression strategy and non-structural proteins) have been found widely and naturally spread in central Europe and the Balkan countries and later, several findings outside Europe confirmed their worldwide distribution (Glasa et al., 2002, 2005; Kollerová et al., 2006; Candresse et al., 2007; Thompson et al.,
2009). High incidence and conserved genome sequence lead to the proposal to classify these isolates in a separate PPV-Rec strain (Glasa et al., 2004b). In fact, PPV-Rec belongs to major PPV strains and its prolonged neglect was caused by inability to serologically distinguish it from the PPV-M. Complete sequencing showed that few amino acid residues different to PPV-M are conserved in PPV-Rec CP (Glasa and Šubr, 2005). Contrary to PPV-M, the strain PPV-Rec was found to infect predominantly plums and only rarely peaches under field conditions. Very faint or no symptoms were recorded in the indicator peach seedlings GF305 (Glasa et al., 2002, 2005). The efficient aphid transmission of PPV-Rec isolates has been demonstrated, although the transmission efficiency varied according to the isolate (Glasa et al., 2004a). Molecular analysis of the PPV genomes revealed that PPV-D, PPV-M, and PPV-Rec isolates share a common 5 ' region as a consequence of ancestral recombination (Glasa et al., 2004b).

The isolate W3174 (Winona) found in a single plum tree in Canada has revealed high sequence differences compared to all known PPV strains so far, thus has been proposed to represent a new strain called PPV-W (James et al., 2003). Singular occurrence of PPV-W in Canada suggested its accidental introduction. Indeed, later reports from Eastern Europe have placed the origin of this strain to this area (Glasa et al., 2011; Sheveleva et al., 2012; Mavrodieva et al., 2013). Analysis of a set of Latvian and Russian PPV-W isolates demonstrated the intra-strain variability of PPV-W higher than that of other PPV strains (Glasa et al., 2011; Sheveleva et al., 2012). Moreover, analysis of the complete genomes has shown that the Canadian isolate W3174 probably originated from homologous recombination events between PPV-W of Latvian type and both PPV-M and PPV-D (Glasa et al., 2011).

Disaccord of various strain-typing strategies applied to some isolates lead originally to the discovery of the PPV-Rec strain and later to the identification of another type of recombinant, originally typed as PPV-M but showing anomalous restriction fragments length polymorphism (RFLP) results and non-reactivity with some PPV-M-specific monoclonal antibodies. Detailed genome analysis revealed a mosaic structure of the $5^{\prime}$ region resulting from recombination events of PPV-M with an unknown source (Glasa and Candresse, 2005) and later classification to a new strain, PPV-T. Other PPV-T isolates have been found in the Anatolian part of Turkey and recently in South-Eastern Europe (Serçe et al., 2009; unpublished data from the SharCo FP7 EU project).

Another group of isolates naturally infecting cherries was detected very recently in Russia (Glasa et al., 2012). Although some similarity with PPV-C has been recorded, the sequence differences (16\% at the full length genome) were too high to classify them in the same virus strain, therefore a new strain called PPV-CR (Cherry Russian) was proposed for these isolates. 


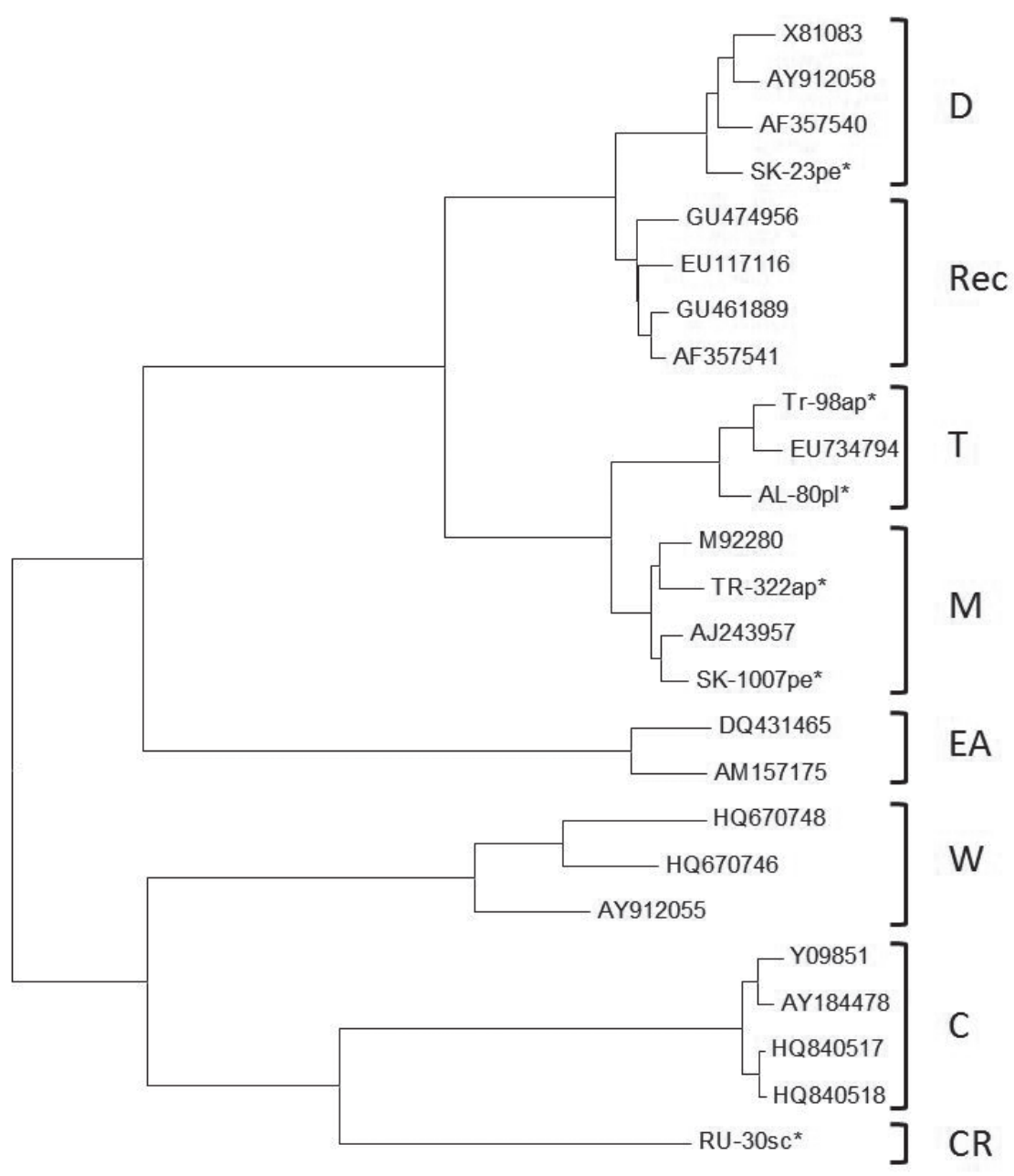

Fig. 1

Unrooted phylogenetic tree of selected PPV isolates based on their complete nucleotide sequences

Strain affiliation is marked in the right margin. The isolates are designed by their GenBank Acc. Nos or Sharco isolate codes $\left(^{*}\right)$ when no Acc. No. available (http://www.sharco.eu/sharco/).

The phylogenetic analysis based on complete viral genome sequences shows that three major strains, together with PPV-T, create a supercluster of the evolutionary related isolates, clearly distinct from other strain clusters (Fig. 1). Growing complexity of intra-species classification shows that PPV variability is higher than believed to be a couple of years ago. Discovery of further virus forms may be anticipated in regions so far poorly understood, particularly in Asia from where the most ancestors of cultivated Prunus species originate.

\section{Diagnostics}

A comprehensive overview of analytical techniques used for detection and typing of PPV is available (Šubr and Glasa,
2008). Here we would like to shortly compare particular methods and highlight their potential for fast and reliable disease diagnostics.

Woody indicator plants such as peach GF305 or P. tomentosa are used mainly for long-term in vivo maintenance of the virus and for special biological experiments. Their application for diagnostic purposes is, however, strongly restricted in comparison with other techniques due to the laboriousness, slowness (taking several months), space demand and unreliability. Moreover, particular PPV strains do not seem to infect these indicators with equal effectiveness (as in the case of GF305 and PPV-Rec), which may lead to the distortion of results, especially in natural mixed infections (Šubr et al., 2006).

Immunochemical methods still play an important role in the diagnostics of plant viruses as those are usually good 
Table 1. Overview of published PPV strain-specific monoclonal antibodies

\begin{tabular}{ll}
\hline Strain specifity & Citation \\
\hline PPV-D & Cambra et al. (1994) \\
PPV-M* & Boscia et al. (1997) \\
PPV-EA & Myrta et al. (1998) \\
PPV-C & Myrta et al. (2000) \\
PPV-W & Croft et al. (2008)
\end{tabular}

*Declared PPV-M-specific antibodies also bind the later discovered PPV-Rec.

immunogens. Antibodies against artificially expressed nonstructural viral proteins may be used in particular, however, the antibodies raised against the $\mathrm{CP}$ are mostly applied because of the simple antigen purification and abundance of CP in the infected cells. High variability of the N-terminal CP region enables the preparation of strain-specific antibodies using intact virions as antigen (Shukla et al., 1989). ELISA of various formats is the most frequently applied method using either polyclonal antisera or monoclonal antibodies (MAbs) of various specificities. Specific MAbs against respective PPV strains have been prepared (Table 1). However, because of the potential escape of some PPV isolates from the typing with MAbs (Candresse et al., 1998), the immunochemical detection is recommended to be supplemented with an independent molecular test for detailed strain analysis. Anti-PPV MAb 5B-IVIA is a broad-specific detection tool reacting with nearly all PPV isolates (Cambra et al., 1994, 2006). However, recently discovered PPV-CR isolates differ in the epitope recognized by this MAb (Candresse et al., 2011) and do not bind it effectively under standard conditions (Glasa et al., 2012).

Immunoblotting combines the advantages of specific reaction with antibodies and electrophoretic separation. It is not applicable for simultaneous analysis of a high number of samples such as ELISA but provides additional information about antigen mobility in the gel. The isolates of major PPV strains may usually be discriminated by the CP electrophoretic pattern (see Capsid protein).

Both the used antibody and the type of immunochemical test are important for the detection specificity. An example of this is how MAb AL declared PPV-M-specific in DASELISA (Boscia et al., 1997) has been shown to react strongly with PPV-Rec and very weak or not at all with PPV-M in immunoblots (Šubr and Glasa, 2004).

RT-PCR is much more sensitive than immunochemical methods. The main disadvantage of amplification methods represents the need for RNA isolation prior to analysis. The use of the strain-specific primer pairs enables detection of the virus and its partial characterization. For this purpose, highly variable PPV genome parts are suitable. The region spanning the 5 '-terminal end of the CP gene was proven to be useful for recognizing not only divergent strains like EA, W and C but also more similar strains $\mathrm{M}, \mathrm{D}$ and Rec. Specific primers have been designed discriminating these major strains in a multiplex PCR format (Šubr et al., 2004b) or enabling specific detection of the single strains (PPV-W and PPV-CR; Glasa et al., 2011, 2012). Another option for strain detection is PCR followed by RFLP analysis (Wetzel et al., 1991a; Glasa et al., 2002). As RFLP is sensitive to single nucleotide substitutions, some isolates may be classified erroneously in this way (Glasa and Candresse, 2005). Therefore, the most reliable method for strain characterization remains partial genome sequencing targeting a highly informative genome region.

\section{Epidemiological aspects of PPV infections}

PPV is naturally spread by several aphid species in a nonpersistent manner, making control of the virus by the vector fighting problematic. Aphid transmission plays an important role in the local, mostly intra-orchard, virus spread. The role of several herbaceous plant species as virus reservoirs cannot be excluded, as experimental transmission of PPV between them and a Prunus host by the aphid Myzus persiceae has been demonstrated (Manachini et al., 2007). Horizontal virus transmission through infected scions and buds is also highly effective. The main factor of long distance spread therefore remains the human activity connected with plant material marketing and transport (Anonymous, 2004).

Particular PPV strains can possess various epidemiological values depending on their geographic localization and prevalent cultivated crop in the region. For example, PPV-M is generally regarded as a very severe strain, while PPV-D is taken as relatively less epidemic in the western Mediterranean region. One of the reasons should be that natural hosts of PPV-M (peach, nectarine, possibly apricot) are much more economically important in this territory than plums hosting predominantly PPV-D (Labonne and Dallot, 2006).

The endemic spread of PPV in most of the Central- and South-eastern European countries involves three major strains (M, D, Rec). An epidemiological survey from Slovakia shows PPV-D as having fully spread in all regions, probably representing the autochthonous strain. PPV-M was found to occur in peaches in the south-western part of Slovakia where most local peach-growing orchards are concentrated. PPV-Rec was found mainly in the western and northern part of the country (Fig. 2). A strong link between PPV-Rec and the old plum orchards planted with the material introduced in the 1980s and 1990s from Serbia with tolerant plum cultivars probably explains the spread of PPV-Rec in this region (Glasa et al., 2004b, 2005). The aforementioned host preference deduced from the natural occurrence of PPV 
strains was also confirmed experimentally (Šubr et al., 2006; Nagyová et al., 2012a).

Strain-mixed infection of a single tree has occasionally been detected under field conditions (Candresse et al., 1998; Myrta et al., 1998; Kollerova et al., 2006; Kajic et al., 2008). Its frequency may be much higher particularly in regions where the three major PPV strains have vastly spread, however, it can be easily overlooked because of the uneven distribution of the virus in the tree canopy. Long-term coexistence of PPV-M and PPV-D in particular trees has been demonstrated (Nagyová et al., 2012a). Competitiveness of PPV isolates in herbaceous host plants differed from natural host preference and did not reveal strain-specific behavior (Šubr et al., 2004a; Glasa et al., 2010).

PPV microevolution at the single tree level under insectfree conditions has lead to a specific pattern of virus subpopulations evolving in particular branches (Jridi et al., 2006). Untreated tree in the field with free aphid stream however, did not show a similar clear-cut structured picture probably due to the permanent mixing of sub-populations by exogenous factors (Predajňa et al., 2012b). Despite a high theoretical mutation rate of RNA viruses, PPV showed relatively high conservation of the dominant sequence population (Schneider and Roossinck, 2001; Predajňa et al., 2012b). The complete genome nucleotide sequence of analyzed PPV-M isolate VAR-2 changed over the course of six years at only $0.3 \%$ showing $0.1-0.3 \%$ divergence depending on the host species (Šubr et al., 2012).

\section{Expression strategy and non-structural proteins}

PPV genome resembles that of other potyviruses. The approximately $9700 \mathrm{nt}$ long (+)ssRNA is 3 '-polyadenylated and contains a covalently bound virus-coded protein on the 5'-end (Laín et al., 1988; Riechmann et al., 1989). It codes for a single large polyprotein of $355.5 \mathrm{kDa}$ starting with the second AUG codon by a leaky scanning mechanism (Riechmann et al., 1992; Simón-Buela et al., 1997). Particular mature polypeptides are released from the polyprotein by autocatalytic proteolysis driven by three viral protease domains (Fig. 3). Most potyviral proteins are known or presumed to be multifunctional. PPV is among the best studied potyviruses from the molecular point of view. However, some properties and functions of its proteins have been predicted by analogy with other members of the genus Potyvirus.

P1 (the first protein) is the most variable potyviral protein with both recombination and gene duplication occurring in its evolutionary history (Valli et al., 2007). A serine protease activity (family S30) is located in the P1 C-terminal domain which cleaves the P1 from the rest of the polyprotein (Adams et al., 2005). The main function of P1 in the infection however, probably does not rely on its proteolytic action.

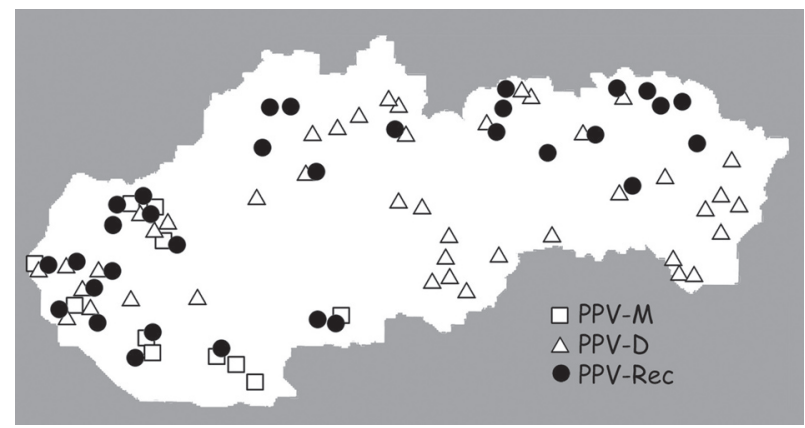

Fig. 2

Distribution of PPV strains in the Slovak Republic

The map is based on the screening effectuated in 2002-2012 (Z. Šubr, unpublished results).

P1 is clearly connected with the virus host specificity and symptom manifestation (Maliogka et al., 2012; Nagyová et al., 2012b). It binds RNA and interacts with the host chloroplast Rieske Fe/S protein (Shi et al., 2007). P1 cooperates with HC-pro in the inhibition of plant posttranscriptional gene silencing (PTGS) defence and its involvement in genome amplification has been presumed, too (Valli et al., 2006; Verchot and Carrington, 1995).

For more than 35 years the HC-pro has been known as helper factor essential for dissemination of potyviruses by aphids (Govier et al., 1977). The amino acid motifs PTK and KITC interact with the viral CP motif DAG and the internal surface of aphid stilets, respectively, creating a molecular bridge and mediating non-persistent virus transmission (Seo et al., 2010). HC-pro also contains a cystein protease domain (C6 family) acting on its own C terminus (Urcuqui-Inchima et al., 2001; Adams et al., 2005). More recently, HC-pro became the first example of plant viral proteins active in host PTGS inhibition (Roth et al., 2004). Involvement of HC-pro in the long distance movement through the plant has also been presumed based on deletion analysis (Yap et al., 2009).

$\mathrm{P} 3$, the third protein is similar to the $\mathrm{P} 1$ in its variability among different potyvirus species and conservation in frame of species, which implies its involvement in specific virushost interactions. Various pathotypes have been mapped to the P3 gene of pea seed-borne mosaic virus (Hjulsager et al., 2006). The toxicity for bacteria in prokaryotic expression experiments and presence of one or two hydrophobic domains indicated the P3 affinity to cellular membranes (Rodríguez-Cerezo and Shaw, 1991; Šubr et al., 2000). Cytological localization of P3 in endoplasmatic reticulum confirmed this hypothesis (Eiamtanasate et al., 2007). Chung et al. (2008) discovered an alternative shorter P3 variant in vivo, resulting from a +2 translation frameshift to so-called PIPO (pretty interesting potyviral ORF). P3N-PIPO has been shown to be essential to the virus infectivity, probably due to affecting the cell-to-cell movement (Wei et al., 2010). 


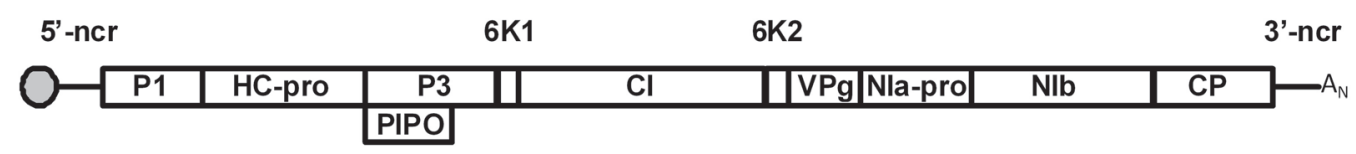

Fig. 3

Scheme of the PPV genome

The grey circle represents covalently bound VPg, $\mathrm{A}_{\mathrm{N}}$ the polyA tail. Dashed arrows show specific activities of three viral proteases at polyprotein processing.

$6 \mathrm{~K} 1$ is a short polypeptide, the function of which is so far unknown. It has just recently been detected in PPV-infected plants in the mature $6 \mathrm{kDa}$ form (Walterman and Maiss, 2006). Although processing at the P3-6K1 junction has been shown not to be essential to the viability of the virus, the infection was symptomless and a compensative mutation was required for virus accumulation if $6 \mathrm{~K} 1$ remained bound to the P3 (Riechmann et al., 1995).

$\mathrm{CI}$ is mainly found as a compound of cylindrical cytoplasmic inclusions of typical pinwheel shape in infected cells. CI shows NTP-ase and RNA helicase activities involved in the unfolding of RNA duplexes during viral genome replication (Fernández et al., 1995, 1997; Laín et al., 1990; 1991). It also plays a role in the potyvirus cell-to-cell movement through plasmodesmata (Roberts et al., 1998). CI interacts with photosystem I PSI-K protein (Jiménez et al., 2006) and may serve as a pathogenic determinant (Seo et al., 2009).

$6 \mathrm{~K} 2$, another $6 \mathrm{kDa}$ polypeptide is likely to play a role in the anchoring of the potyviral replication complex to cellular membrane structures through its central hydrophobic domain (Schaad et al., 1997). Its involvement in vascular movement has also been hypothesized (Rajamäki and Valkonen, 1999).

VPg is an intrinsically disordered protein (Hébrard et al., 2009). It is covalently linked through a tyrosine residue by a phosphodiester bond to the 5 '-terminus of PPV genomic RNA (Murphy et al., 1991; Puustinen et al., 2002) and mimics the function of eukaryotic cap structure by binding translation initiation factors and protecting the viral genome (Robaglia and Caranta, 2006). VPg has an NTP-binding site and may serve as a primer for potyviral genome replication (Puustinen and Mäkinen, 2004). Competition in binding the initiation factor eIF4E or degradation of plant mRNAs by VPg ribonuclease activity may interfere with and hinder the host proteosynthesis (Grzela et al., 2006; Cotton et al., 2006). ATPase activity of the VpG has been recently demonstrated and presented in connection with its potential functions, particularly with cell-to-cell or long distance movement of potyviruses (Mathur and Savithri, 2012).

NIa-pro is the enzyme responsible for cleavage of most sites in PPV polyprotein. It is a cysteine (C4) protease with structural motifs similar to eukaryotic serine proteases (Adams et al., 2005). Interaction with viral replicase (NIb) and non-specific binding of RNA also implies the involvement of NIa-pro in the replication process (Guo et al., 2001; Daros and Carrington, 1997). Nuclear localization of NIa-pro in the late infection stage together with demonstrated deoxyribonuclease activity could imply its action in degradation of the host DNA (Anindya and Savithri, 2004).

NIb is a viral replicase (RNA-dependent RNA polymerase). Potyviral replication complex is anchored in membrane structures and involves several viral and host proteins (Restrepo-Hartwig and Carrington, 1994). RNA polymerase activity has been proposed to be activated by interaction of $\mathrm{NIb}$ with a VPg-NIa-pro precursor. Nuclear localization signals found in the NIb sequence enable the transport to plant cell nuclei where they are accumulated together with NIa in inclusion bodies (Li et al., 1997).

\section{Capsid protein}

In assembled virions viral RNA is protected by about 2000 copies of CP. It is the best characterized potyviral protein for several reasons. CP is the unique structural protein of the capsid, thus it is well understood serologically. It is derived from the $\mathrm{C}$ terminus of the polyprotein and there are more sequence data available from the 3 ' -proximal genome part than from other regions. Although the primary CP function is the formation of virions, this protein is involved in several infection-related actions (Salvador et al., 2006; Decroocq et al., 2009). NTPase activity of the potato virus A (PVA) CP has been demonstrated to have no known function as of yet in the infection cycle (Rakitina et al., 2005).

The CP structure comprises three domains (Baratova et al., 2001; Shukla et al., 1988). The central domain called the core $\mathrm{CP}$ interacts with viral RNA in matured virions. In addition to encapsidation it is involved in replication and interacts with plasmodesmata in the process of cell-to-cell movement (Varrelmann and Maiss, 2000; Rojas et al., 1997; Dolja et al., 1995). Both C- and N-terminal domains are exposed on the surface of viral particles. C-terminal domain plays a role in encapsidation and long-distance movement (Dolja et al., 1995; Kang et al., 2006).

While core CP and the C terminus are relatively conserved, the $\mathrm{N}$-terminal domain is the most variable part 
of the polyprotein. It bears species- and strain-specific epitopes and is highly immunogenic (Shukla et al., 1989). It is probably involved in systemic vascular movement (Dolja et al., 1994; Szathmáry et al., 2009). An appropriate net charge rather than a specific amino acid sequence of the CP is required for potyvirus movement (Arazi et al., 2001; Kimalov et al., 2004; López-Moya and Pirone, 1998). The aphid transmission is enabled by the CP interaction with HC-pro as previously mentioned. The DAG motif localized close to the $\mathrm{CP} \mathrm{N}$ terminus is responsible for this interaction and its mutation or deletion abolishes the aphid transmissibility (Blanc et al., 1997). Natural or prepared aphid-non-transmissible forms of PPV have been described as bearing mutations or deletions close to the $\mathrm{N}$ terminus of CP (Breyel et al., 1986; Navrátil et al., 1998). Deletions excluding the DAG motif did not affect the transmissibility (Szathmáry and Palkovics, 2009; Szathmáry et al., 2009). Mild trypsinolysis of virions is able to remove both $\mathrm{CP}$ termini and leads to particles containing the core CP. Such particles are indistinguishable from native virions by electron microscopy and they are still infectious but not aphid transmissible due to the lack of the DAG motif (Shukla et al., 1988).

The CP mobility in SDS-PAGE differs to some extent for particular PPV isolates (Fig. 4). It has been shown to depend on their strain affiliation (Ranković and Veliković, 1983). CP of PPV-M migrated slower than that of PPV-D and different molecular masses ( 38 and $36 \mathrm{kDa}$ ) have been predicted for CP of these strains based on this approach (López-Moya et al., 1994; Bousalem et al., 1994). CP of PPV-Rec migrates as a double-band in SDS-PAGE (Kollerová et al., 2008). The CP electrophoretic phenotype may be used for fast classification of these major PPV strains, however confirmation by an independent genome analysis is required as few exceptions to the aforementioned CP mobility rules have been observed (Šubr and Glasa, 1999).

Different electrophoretic profiles of the CP did not depend on the host plant species or infection stage but they were reproducibly connected with the strain affiliation of PPV isolates. In silico analysis of accumulated sequence data indicated almost equal theoretical molecular weight values for the CP of different strains (about $36.5 \mathrm{kDa}$ ). This fact is inconsistent with variable CP mobility in SDS-PAGE, which is apparently caused by non-amino acid compounds coupled with CP molecules by posttranslational modification (Šubr and Glasa, 2004; Kollerová et al., 2008). O-glycosylation of $\mathrm{CP}$ serine and threonine residues by $\mathrm{N}$-acetylglycosamine has been detected and the corresponding plant enzyme was identified (Fernández-Fernández et al., 2002; Chen et al., 2005; Scott et al., 2006). Localization of this modification in the N-terminal CP part is in agreement with the fact that core CP of different PPV strains migrated equally in SDS-PAGE (Pérez et al., 2006; Šubr and Glasa, 1999).

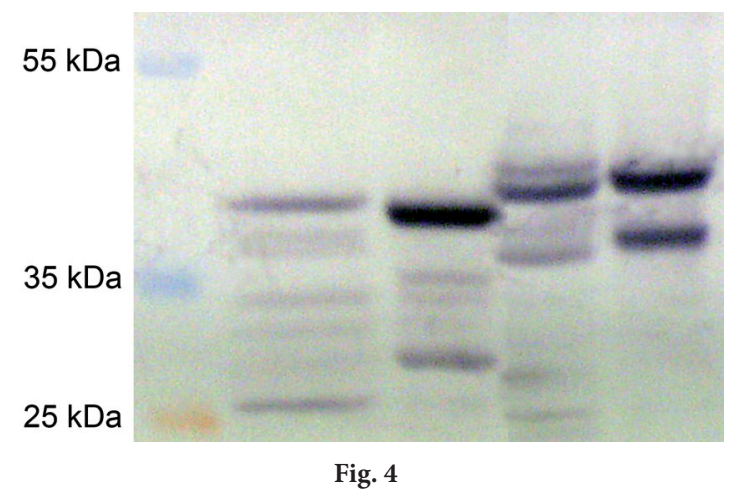

Immunoblot analysis of PPV CP from representative isolates of four PPV strains

From left to right: prestained molecular mass marker, isolate RU-30sc (PPVCR), Rankovic (PPV-D), BOR-3 (PPV-Rec), and SK68 (PPV-M). In addition to major bands of intact $\mathrm{CP}$, several proteolytic products are recognized by the polyclonal antibody in crude homogenates from infected plants.

Phosphorylation of PPV CP has also been proven (Fernández-Fernández et al., 2002). In PVA phosphorylation down-regulated the CP-RNA binding, suggesting the involvement in regulation of the relative amount of viral RNA available for early or late infection events (Ivanov et al., 2001). Moreover, it influenced the ability of cell-to-cell and long distance movement (Ivanov et al., 2003). The balance between phosphorylation and glycosylation may be a control or regulatory factor involved in the viral infection cycle. However, phosphorylation unlike glycosylation is not restricted to the $\mathrm{N}$-terminal CP domain in PPV, as the core $\mathrm{CP}$ reacted with anti-phosphoprotein antibodies (Kollerová et al., 2008). Differences in partial phosphorylation cause the typical double-band CP electrophoretic profile of the strain PPV-Rec as demonstrated by in vitro dephosphorylation (Šubr et al., 2007). The PPV-Rec electrophoretic phenotype has been precisely mapped to the single amino acid in the position 66. Arginine in this position lead to conversion to a single-band profile while glycine was present in common double-band CP form. Steric hindering of the access for plant kinase to closely located serine or threonine residues by more voluminous arginine may explain the different phenotypes (Šubr et al., 2010a). Similar CP double-band phenotype has also been observed in some PPV-W isolates but it was unrelated to the amino acid in position 66 (Sheveleva et al., 2012).

\section{Infectious clones and PPV-based expression vectors}

Previously mentioned analysis of the CP is a good example for the application of infectious clones of RNA viruses in their research. Because of problematic manipulation with and direct analysis of RNA, the genome of RNA viruses is 
reverse transcribed into cDNA and cloned under the control of appropriate prokaryotic promoter. Cloned cDNA may be specifically manipulated by standard techniques of recombinant DNA and subsequently transferred into virus host plant as infectious cDNA or as infectious transcript obtained in vitro (Nagyová and Šubr, 2007). While mechanical leaf inoculation is usually sufficient for infection by RNA, biolistic method has to be applied to infect plants efficiently by cDNA, in order to deliver it to the nucleus sustaining the cell viability (López-Moya and García, 2000; Šubr et al., 2010b). As an alternative to commercial devices, various simpler gene delivery systems may be applied (Gray et al., 1994; Sikorskaite et al., 2010) including sport air guns with either inert metals (gold, tungsten) or diatomaceous earth (Celite) used as nucleic acid carriers (Predajňa et al., 2010; Nagyová et al., 2011).

Infectious clones of several PPV isolates have been constructed (Maiss et al., 1992; Riechmann et al., 1990; Sáenz et al., 2000; Predajňa et al., 2012a) and applied for studies of the infectious cycle and particularly for mapping various phenotypes in the PPV genome. Varrelmann and Maiss (2000) demonstrated two motifs in the CP essential for systemic transport of the infectious clone PPV-NAT (strain PPV-D). Wild CP provided by the transgene host plant complemented the defect $\mathrm{CP}$ and restituted the ability of systemic infection. The study of recombination between CP-defective PPV and transiently expressed $\mathrm{CP}$ gene showed that complete 3 '-NCR was essential to this process (Varrelmann et al., 2000). Infectious cloning of PPV-NAT was used for the first demonstration of potyviral $6 \mathrm{~K} 1$ peptide in vivo. A histidine tag attached to $6 \mathrm{~K} 1$ enabled its enrichment from the infected plant material followed by immunodetection (Waltermann and Maiss, 2006).

ß-glucuronidase gene was inserted between $\mathrm{P} 1$ and HC-pro of an infectious clone based on the PPV isolate R (strain PPV-D). The plants infected by in vitro transcripts were symptomless and passage used to lead to full extinction of infection due to deleterious mutations (Guo et al., 1998). Subsequently prepared infectious cDNA clone of this isolate called pIC-PPV (López-Moya and García, 2000) was improved by insertion of a plant intron in the gene $\mathrm{P} 3$ which has been shown to be toxic for E. coli during the cloning steps (Maiss et al., 1992; Šubr et al., 2000). This clone together with the clone of PPV isolate PS (strain PPV-M) was successfully applied in order to map the pathogenicity determinants in the PPV genome. Construction and analysis of inter-strain chimeras revealed the central genome part (C-terminal P3$6 \mathrm{~K} 1)$ to be responsible for the pathogenicity in Nicotiana clevelandii and Pisum sativum (Sáenz et al., 2000). Later on, biological properties of such chimeras in woody host plants were analyzed. While the $\mathrm{P} 3-6 \mathrm{~K} 1$ region was critical for the systemic infection of plums, a more complex picture was obtained for peaches (Dallot et al., 2001). Salvador et al. (2008) mapped the restricted host infectivity (peach or $N$. clevelandii) in two PPV isolates in various parts of the viral genome, particularly in the 5 '-end and the N-terminal CP region. Inter-strain chimeric clones with pIC-PPV were used to demonstrate that $\mathrm{N}$-terminal $\mathrm{CP}$ is the only polyprotein part influencing the CP electrophoretic mobility and for mapping PPV-Rec double-band electrophoretic phenotype (Šubr et al., 2010a). A single amino acid residue in the 3 '-proximal part of the P1 gene was demonstrated to determine the PPV symptom expression in N. occidentalis and Nicandra physaloides (Nagyová et al., 2012 and unpublished data). An infectious cDNA clone of PPV-M isolate SK68 (Palkovics et al., 1993) has been used for optimizing the infection of Arabidopsis thaliana protoplasts and the following study of virus replication in this system (Raghupathy et al., 2006). A detailed genomic study of factors induced and repressed by the infection showed the significant infection-related regulation of 3500 plant genes (Babu et al., 2008).

Once an infectious clone has been prepared, it is a relatively short way to its adaptation and usage as a viral vector for transient expression of foreign genes in plants (Nagyová and Šubr, 2007). Application of the PPV genome for this purpose has also been published (García et al., 2006). Epitope presentation vectors have been used to produce viral pseudoparticles with foreign amino acids exposed on their surface (fused with the N-terminal CP). Potential vaccines against canine parvovirus and feline immunodeficiency virus have been prepared and successfully tested (Fernández-Fernández et al., 1998, 2002). PPV-based vectors for intact protein production with cloning sites either between P1 and HC-pro (Guo et al., 1998) or between NIb and CP genes have been prepared (Dietrich and Maiss, 2003; Fernández-Fernández et al., 2001). VP60 structural protein of rabbit hemorrhagic disease virus was expressed using such vector in plants and used to protect rabbits against a lethal challenge with this virus (Fernández-Fernández et al., 2001). Biologically safe vectors for epitope presentation and free protein expression based on the genome of PPV-Rec are currently being tested (Kamencayová and Šubr, 2012).

\section{Conclusion}

PPV is the only known potyvirus infecting Prunus spp. Since the beginning of the $20^{\text {th }}$ century, the Sharka disease has spread through many countries where Prunus trees are planted and has dramatically affected stone fruit production especially in southern and central Europe. Because of the non-persistent character of natural aphid transmission, the application of insecticides provides no efficient protection from the spread of the virus. Moreover, human activity is obviously the main factor in the broad dissemination of PPV. In the regions with endemic incidence of PPV, the defence 
strategy should rely on the cultivation of virus-resistant plant cultivars, however, their availability is still restricted. The character of PPV research has changed gradually from biological and epidemiological studies to the analysis of the genome and its directed mutagenesis (enabling back investigation of the influence of these changes on biological properties). Continuously increasing knowledge on the pathogen may further strengthen currently used control strategies and make them more efficient. Therefore the progress, in analytical detection methods and discovery of virus-host interactions on molecular, plant and epidemiological levels brings hope for the application of research results in more effective plant protection.

Acknowledgements. This study was supported by the grants APVV-0042-10 from the Slovak Research and Development Agency, 2/0008/12 from the Scientific Grant Agency of Ministry of Education and Slovak Academy of Sciences, HUSK/0901/1.2.1/0126 of the Hungary-Slovakia Cross-border Co-operation Programme through the European Regional Development Fund and partially by the European Community's Seven Framework Programme under Grant Agreement No. 204429 (SharCo project).

\section{References}

Adams MJ, Antoniw JF, Beaudoin, F, Mol. Plant Pathol. 6, 471-487, 2005. http://dx.doi.org/10.1111/j.13643703.2005.00296.x

Anindya R, Savithri HS, J. Biol. Chem. 279, 32159-32169, 2004. http://dx.doi.org/10.1074/jbc.M404135200

Anonymous, EPPO Bull. 34, 247-256, 2004.

Arazi T, Shiboleth YM, Gal-on A, J. Virol. 75, 6329-6336, 2001. http://dx.doi.org/10.1128/JVI.75.14.6329-6336.2001

Atanasoff D, Phytopathol. Z. 8, 259-284, 1935.

Babu M, Griffiths JS, Huang T-S, Wang A, BMG Genomics 9, 325 (http://www.biomedcentral.com/1471-2164/9/325), 2008.

Baratova LA, Efimov AV, Dobrov EN, Fedorova NV, Hunt R, Badun GA, Ksenofontov AL, Torrance L, Järvekülg L, J. Virol. 75, 9696-9702, 2001. http://dx.doi.org/10.1128/ JVI.75.20.9696-9702.2001

Blanc S, LopezMoya JJ, Wang RY, GarciaLampasona S, Thornbury DW, Pirone TP, Virology 231, 141-147, 1997. http:// dx.doi.org/10.1006/viro.1997.8521

Bodin M, Glasa M, Verger D, Costes E, Dosba F, J. Phytopathol. 151, 625-630, 2003. http://dx.doi.org/10.1046/j.09311785.2003.00777.x

Boscia D, Zeramdini H, Cambra M, Potere O, Gorris MT, Myrta A, Di Terlizzi B, Savino V, Eur. J. Plant Pathol. 103, 477-480, 1997. http://dx.doi.org/10.1023/A:1008674618635

Bousalem M, Candresse T, Quiotdouine L, Quiot JB, J. Phytopathol. 142, 163-172, 1994. http://dx.doi. org/10.1111/j.1439-0434.1994.tb04526.x

Breyel E, Maiss E, Casper R, El-Ouaghlidi F, Acta Hort. 193, 167-172, 1986.
Cambra M, Asensio M, Gorris MT, Pérez E, Camarasa E, García JA, Moya JJ, Lopez-Abella D, Vela C, Sanz A, EPPO Bull. 24, 569-577, 1994

Cambra M, Boscia D, Myrta A, Palkovics L, Navrátil M, Barba M, Gorris MT, Capote N, EPPO Bull. 36, 254-261, 2006.

Candresse T, Cambra M, Dallot S, Lanneau M, Asensio M, Gorris MT, Revers F, Macquaire G, Olmos A, Boscia D, Quiot JB, Dunez J, Phytopathology 88, 198-204, 1998. http:// dx.doi.org/10.1094/PHYTO.1998.88.3.198

Candresse T, Saenz P, García JA, Boscia D, Navratil M, Gorris MT, Cambra M, Phytopathology 101, 611-619, 2011. http:// dx.doi.org/10.1094/PHYTO-10-10-0274

Candresse T, Svanella-Dumas L, Gentit P, Caglayan K, Cevik B, Plant Dis. 91, 331, 2007. http://dx.doi.org/10.1094/ PDIS-91-3-0331B

Cervera MT, Riechmann JL, Martin MT, García JA, J. Gen. Virol. 74, 329-334, 1993. http://dx.doi.org/10.1099/0022-131774-3-329

Chen D, Juarez S, Hartweck L, Alamillo JA, Simon-Mateo C, Perez JJ, Fernandez-Fernandez MR, Olszewski NE, Garcia JA, J. Virol. 79, 9381-9387, 2005. http://dx.doi.org/10.1128/ JVI.79.15.9381-9387.2005

Chung BYW, Miller WA, Atkins JF, Firth AE, PNAS 105, 5897-5902, 2008. http://dx.doi.org/10.1073/pnas.0800468105

Cotton S, Dufresne PJ, Thivierge K, Ide C, Fortin MG, Virology 351, 92-100, 2006. http://dx.doi.org/10.1016/j. virol.2006.03.019

Crescenzi A, Nuzzaci M, Piazzolla P, Levy L, Hadidi A, Acta Hort. 386, 219-225, 1995.

Croft H, Malinowski T, Krizbai L, Mikec I, Kajic V, Reed C, Varga A, James D, J. Virol. Methods 153, 203-213, 2008. http:// dx.doi.org/10.1016/j.jviromet.2008.07.016

Dallot S, Labonne G, Boeglin M, Quiot-Douine L, Quiot JB, Candresse T, Acta Hort. 472, 355-365, 1998.

Dallot S, Quiot-Douine L, Sáenz P, Cervera MT, García J-A, Quiot J-B, Virology 91, 159-164, 2001.

Daros JA, Carrington JC, Virology 237, 327-336, 1997. http:// dx.doi.org/10.1006/viro.1997.8802

Decroocq V, Salvador B, Sicard O, Glasa M, Cosson P, SvanellaDumas L, Revers F, García JA, Candresse T, MPMI 22, 1302-1311, 2009. http://dx.doi.org/10.1094/MPMI-22$\underline{10-1302}$

Dietrich C, Maiss E, J. Gen. Virol. 84, 2871-2876, 2003.

http://dx.doi.org/10.1099/vir.0.19245-0

Dolja VV, Haldeman-Cahill R, Montgomery AE, Vandenbosch KA, Carrington JC, Virology 206, 1007-1016, 1995. http:// dx.doi.org/10.1006/viro.1995.1023

Dolja VV, Haldeman R, Robertson NL, Dougherty WG, Carrington JC, EMBO J. 13, 1482-1491, 1994.

Eiamtanasate S, Juricek M, Yap YK, Virus Genes 35, 611-617, 2007. http://dx.doi.org/10.1007/s11262-007-0114-z

Fanigliulo A, Comes S, Maiss E, Piazzolla P, Crescenzi A, Arch. Virol. 148, 2137-2153, 2003. http://dx.doi.org/10.1007/ s00705-003-0175-9

Fernández A, Guo HS, Saenz P, SimonBuela L, deCedron MG, Garcia JA, Nucl. Acids Res. 25, 4474-4480, 1997.

Fernández A, Lain S, Garcia JA, Nucl. Acids Res. 23, 1327-1332, 1995. http://dx.doi.org/10.1093/nar/23.8.1327 
Fernández-Fernández MR, Camafeita E, Bonay P, Méndez E, Albar JP, García JA, J. Biol. Chem. 277, 135-140, 2002. http:// dx.doi.org/10.1074/jbc.M106883200

Fernández-Fernández MR, Martinez-Torrecuadrada JL, Casal JI, Garcia JA, FEBS Lett. 427, 229-235, 1998. http://dx.doi. org/10.1016/S0014-5793(98)00429-3

Fernández-Fernández MR, Mourino M, Rivera J, Rodriguez F, Plana-Duran J, Garcia JA, Virology 280, 283-291, 2001. http://dx.doi.org/10.1006/viro.2000.0762

Hébrard E, Bessin Y, Michon T, Longhi S, Uversky VN, Delalande F, Van Dorsselaer A, Romero P, Walter J, Declerck N, Fargette D, Virology J. 6, 23, 2009. http://dx.doi. org/10.1186/1743-422X-6-23

Hjulsager CK, Olsen BS, Jensen DMK, Cordea MI, Krath BN, Johansen IE, Lund OS, Virology 355, 52-61, 2006. http:// dx.doi.org/10.1016/j.virol.2006.07.016

García JA, Cambra M, Plant Viruses 1, 69-79, 2007.

Glasa M, Candresse T, Virus Res. 108, 199-206, 2005. http://dx.doi. org/10.1016/j.virusres.2004.09.009

García JA, Lucini C, Garcia B, Alamillo JM, Lopez-Moya JJ, EPPO Bull. 36, 341-345, 2006.

Glasa M, Boeglin M, Labonne G, Acta Hort. 657, 217-220, 2004a.

Glasa M, Malinowski T, Predajňa L, Pupola N, Dekena D, Michalczuk L, Candresse T, Phytopathology 101, 980-985, 2011. http://dx.doi.org/10.1094/PHYTO-12-10-0334

Glasa M, Marie-Jeanne V, Labonne G, Šubr Z, Kúdela O, Quiot JB, Eur. J. Plant Pathol. 108, 843-853, 2002. http://dx.doi. org/10.1023/A:1021294221878

Glasa M, Palkovics L, Komínek P, Labonne G, Pittnerová S, Kúdela O, Candresse T, Šubr Z, J. Gen. Virol. 85, 2671-2681, 2004b. http://dx.doi.org/10.1099/vir.0.80206-0

Glasa M, Paunovic S, Jevremovic D, Myrta A, Pittnerová S, Candresse T, Arch. Virol. 150, 2051-2060, 2005. http://dx.doi. org/10.1007/s00705-005-0548-3

Glasa M, Predajňa L, Šubr Z, J. Plant Pathol. 92, 267-271, 2010.

Glasa M, Prichodko Y, Zhivaeva T, Shneider Y, Predajňa L, Šubr Z, Candresse T, 22nd Int. Conf. on Virus and Other Graft Transmis. Dis. of Fruit Crops, Rome, p. 37, 2012.

Glasa M, Svanella L, Candresse T, Arch. Virol. 151, 1679-1682, 2006. http://dx.doi.org/10.1007/s00705-006-0781-4

Glasa M, Šubr ZW, Phytopathol. Polon. 36, 41-46, 2005.

Govier DA, Kassanis B, Pirone TP, Virology 78, 306-314, 1977. http://dx.doi.org/10.1016/0042-6822(77)90101-5

Gray DJ, Hiebert E, Lin CM, Compton ME, McCooley DW, Harrison RJ, Gaba VP, Plant Cell Tiss. Org. Cult. 37, 179-184, 1994. http://dx.doi.org/10.1007/BF00043613

Grzela R, Strokovska L, Andrieu JP, Dublet B, Zagorski W, Chroboczek J, Biochimie 88, 887-896, 2006. http://dx.doi. org/10.1016/j.biochi.2006.02.012

Guo HS, López-Moya JJ, García JA, Virus Res. 57, 183-207, 1998. http://dx.doi.org/10.1016/S0168-1702(98)00100-2

Guo DY, Rajamaki ML, Saarma M, Valkonen JPT, J. Gen. Virol. 82, 935-939, 2001.

Ivanov KI, Puustinen P, Gabrenaite R, Vihinen H, Ronnstrand L, Valmu L, Kalkkinen N, Mäkinen K, Plant Cell 15, 2124-2139, 2003. http://dx.doi.org/10.1105/tpc.012567
Ivanov KI, Puustinen P, Merits A, Saarma M, Mäkinen K, J. Biol. Chem. 276, 13530-13540, 2001.

James D, Varga A, Thompson D, Hayes S, Plant Dis. 87, 1119-1124, 2003. http://dx.doi.org/10.1094/PDIS.2003.87.9.1119

Jiménez I, López L, Alamillo JM, Valli A, García JA, MPMI 19, 350358, 2006. http://dx.doi.org/10.1094/MPMI-19-0350

Jridi C, Martin JF, Marie-Jeanne V, Labonne G, Blanc S, J. Virol. 80, 2349-2357, 2006. http://dx.doi.org/10.1128/ JVI.80.5.2349-2357.2006

Kajic V, Cerni S, Krajacic M, Mikec I, Skoric D, J. Plant Pathol. 90, 9-13, 2008.

Kajic V, Černi S, Škoric D, 22nd Int. Conf. on Virus and Other Graft Transmis. Dis. of Fruit Crops, Rome, p. 157, 2012.

Kalashyan JA, Bilkej ND, Verderevskaya TD, Rubina EV, EPPO Bull. 24, 645-649, 1994.

Kamencayová M, Šubr Z, Acta Fytotech. Zootech. 15, 24-26, 2012.

Kang SH, Lim WS, Hwang SH, Park JW, Choi HS, Kim KH, J. Gen. Virol. 87, 225-229, 2006. http://dx.doi.org/10.1099/ vir.0.81499-0

Kerlan C, Dunez J, Ann. Phytopathol. 11, 241-250, 1979.

Kimalov B, Gal-On A, Stav R, Belausov E, Arazi T, J. Gen. Virol. 85, 3421-3430, 2004. http://dx.doi.org/10.1099/ vir.0.80417-0

Kollerová E, Glasa M, Šubr ZW, J. Plant Pathol. 90, S1.19-S1.22, 2008.

Kollerová E, Nováková S, Šubr Z, Glasa M, Plant Dis. 90, 1108, 2006. http://dx.doi.org/10.1094/PD-90-1108C

Labonne G, Dallot S, EPPO Bull. 36, 267-270, 2006.

Laín S, Martin MT, Riechmann JL, Garcia, JA, J. Virol. 65, 1-6, 1991.

Laín S, Riechmann JL, García JA, Nucl. Acids Res. 18, 7003-7006, 1990. http://dx.doi.org/10.1093/nar/18.23.7003

Laín S, Riechmann JL, Méndez E, García JA, Virus Res. 10, 325-342, 1988. http://dx.doi.org/10.1016/0168-1702(88)90074-3

Li XH, Valdez P, Olvera RE, Carrington JC, J. Virol. 71, 1598-1607, 1997.

López-Moya JJ, Canto T, López-Abella D, Díaz-Ruíz JR, Plant Pathol. 43, 164-171, 1994. http://dx.doi. org/10.1111/j.1365-3059.1994.tb00566.x

López-Moya JJ, García JA, Virus Res. 68, 99-107, 2000. http:// dx.doi.org/10.1016/S0168-1702(00)00161-1

López-Moya JJ, Pirone TP, J. Gen. Virol. 79, 161-165, 1998.

Maiss E, Timpe U, Brisskerode A, Lesemann DE, Casper R, J. Gen. Virol. 73, 709-713, 1992. http://dx.doi.org/10.1099/00221317-73-3-709

Malinowski T, Sowik I, Salavei AV, Kukharchyk NV, 22nd Int. Conf. on Virus and Other Graft Transmis. Dis. of Fruit Crops, Rome, p. 152, 2012.

Maliogka VI, Salvador B, Carbonell A, Sáenz P, San León D, Oliveros JC, Delgadillo MO, García JA, Simón-Mateo C, Mol. Plant Pathol. 13, 877-886, 2012. http://dx.doi. org/10.1111/j.1364-3703.2012.00796.x

Manachini B, Casati P, Cinanni L, Bianco P, J. Econ. Entomol. 100, 1047-1052, 2007. http://dx.doi.org/10.1603/00220493(2007)100[1047:ROMPHA]2.0.CO;2

Mathur C, Savithri HS, Biochem. Biophys. Res. Commun. 427, 113 118, 2012. http://dx.doi.org/10.1016/j.bbrc.2012.09.020 
Matic S, Elmaghraby I, Law V, Varga A, Reed C, Myrta A, James, D, J. Plant Pathol. 93, 303-310, 2011.

Mavrodieva VA, James D, Williams KL, Negi S, Varga A, Mock R, Levy L, Plant Dis. 97, 44-52, 2013. http://dx.doi. org/10.1094/PDIS-01-12-0104-RE

Milosevic TM, Glisie IP, Milosevic NT, Glisic IS, Eur. J. Plant Pathol. 126, 73-79, 2010. http://dx.doi.org/10.1007/ s10658-009-9526-Z

Murphy JF, Rychlik W, Rhoads RE, Hunt AG, Shaw JG, J. Virol. 65, 511-513, 1991.

Myrta A, Di Terlizzi B, Boscia D, Caglayan K, Gavriel I, Ghanem G, Varveri C, Savino V, Acta Virol. 42, 251-253, 1998.

Myrta A, Potere O, Crescenzi A, Nuzzaci M, Boscia D, J. Plant Pathol. 82, 95-103, 2000.

Myrta A, Varga A, James D, Arch. Virol. 151, 1189-1198, 2006. http://dx.doi.org/10.1007/s00705-005-0703-x

Nagyová A, Glasa M, Šubr Z, Acta Fytotech. Zootech. 15, 36-38, 2012a.

Nagyová A, Kamencayová M, Glasa M, Šubr ZW, Virus Genes 44, 505-512, 2012b. http://dx.doi.org/10.1007/s11262012-0726-9

Nagyová A, Predajňa L, Glasa M, Šubr ZW, Acta Virol. 55, 365-366, 2011. http://dx.doi.org/10.4149/av_2011_04_365

Nagyová A, Šubr Z, Acta Virol. 51, 223-237, 2007.

Navrátil M, Simonová V, Paprštein F, Karešová R, Acta Hort. 472 (Suppl. 2), 373-379, 1998.

Nemchinov L, Crescenzi A, Hadidi A, Piazzolla P, Verderevskaya T, Plant Virus Disease Control, APS Press, St. Paul, Minnesota, pp. 629-638, 1998.

Palkovics L, Burgyán J, Balázs E, Virus Genes 7, 339-347, 1993. http://dx.doi.org/10.1007/BF01703390

Pasquini G, Barba M, Proc. Middle Eur. Meeting ,96 on Plum Pox, Budapest, pp. 168-171, 1997.

Pérez JD, Juarez S, Chen DH, Scott CL, Hartweck LM, Olszewski NE, Garcia JA, FEBS Lett. 580, 5822-5828, 2006. http:// dx.doi.org/10.1016/j.febslet.2006.09.041

Predajňa L, Nagyová A, Šubr Z, Acta Virol. 54, 303-306, 2010. http://dx.doi.org/10.4149/av_2010_04_303

Predajňa L, Nagyová A, Glasa M, Šubr Z, Acta Virol. 56, 135-138, 2012a. http://dx.doi.org/10.4149/av $2012 \quad 02 \quad 129$

Predajňa L, Šubr Z, Candresse T, Glasa M, Virus Res. 167, 112-117, 2012b. http://dx.doi.org/10.1016/j.virusres.2012.04.002

Puustinen P, Mäkinen K, J. Biol. Chem. 279, 38103-38110, 2004. http://dx.doi.org/10.1074/jbc.M402910200

Puustinen P, Rajamäki ML, Ivanov KI, Valkonen JPT, Mäkinen K, J. Virol. 76, 12703-12711, 2002. http://dx.doi.org/10.1128/ JVI.76.24.12703-12711.2002

Rajamäki ML, Valkonen JPT, MPMI 12, 1074-1081, 1999. http:// dx.doi.org/10.1094/MPMI.1999.12.12.1074

Rakitina DV, Kantidze OL, Leshchiner AD, Solovyev AG, Novikov VK, Morozov SY, Kalinina NO, FEBS Lett. 579, 4955-4960, 2005. http://dx.doi.org/10.1016/j.febslet.2005.07.083

Ranković M, Veliković D, Zaštita Bilja 34, 47-52, 1983.

Raghupathy MB, Griffiths JS, Stobbs LW, Brown DCW, Brandle JE, Wang A, J. Virol. Methods 136, 147-153, 2006. http:// dx.doi.org/10.1016/j.jviromet.2006.05.009

Restrepo-Hartwig MA, Carrington JC, J. Virol. 68, 2388-2397, 1994.
Revers F, Le Gall O, Candresse T, Le Romancer M, Dunez J, J. Gen. Virol. 77, 1953-1965, 1996. http://dx.doi. org/10.1099/0022-1317-77-8-1953

Riechmann JL, Cervera MT, Garcia JA, J. Gen. Virol. 76, 951-956, 1995. http://dx.doi.org/10.1099/0022-1317-76-4-951

Riechmann JL, Laín S, García JA, J. Gen. Virol. 70, 2785-2789, 1989. http://dx.doi.org/10.1099/0022-1317-70-10-2785

Riechmann JL, Laín S, García JA, Virology 177, 710-716, 1990. http://dx.doi.org/10.1016/0042-6822(90)90537-2

Riechmann JL, Laín S, García JA, J. Gen. Virol. 73, 1-16, 1992. http://dx.doi.org/10.1099/0022-1317-73-1-1

Robaglia C, Caranta C, Trends in Plant Science 11, 40-45, 2006. http://dx.doi.org/10.1016/j.tplants.2005.11.004

Roberts IM, Wang D, Findlay K, Maule AJ, Virology 245, 173-181, 1998. http://dx.doi.org/10.1006/viro.1998.9132

Rodríguez-Cerezo E, Shaw JG, Virology 185, 572-579, 1991. http:// dx.doi.org/10.1016/0042-6822(91)90527-I

Rojas MR, Zerbini FM, Allison RF, Gilbertson RL, Lucas WJ, Virology 237, 283-295, 1997. http://dx.doi.org/10.1006/ viro.1997.8777

Roth BM, Pruss GJ, Vance VB, Virus Res. 102, 97-108, 2004. http:// dx.doi.org/10.1016/j.virusres.2004.01.020

Sáenz P, Cervera MT, Dallot S, Quiot L, Quiot J-B, Riechmann JL, Garcia JA, J. Gen. Virol. 81, 557-566, 2000.

Salvador B, Delgadillo MO, Saenz P, Garcia JA, Simon-Mateo C, MPMI 2, 20-29, 2008. http://dx.doi.org/10.1094/MPMI21-1-0020

Salvador B, Garcia JA, Simon-Mateo C, EPPO Bull. 36, 229-238, 2006.

Schaad MC, Lellis AD, Carrington JC, J. Virol. 71, 8624-8631, 1997.

Schneider WL, Roossinck MJ, J. Virol. 75, 6566-6571, 2001. http:// dx.doi.org/10.1128/JVI.75.14.6566-6571.2001

Scholthof KBG, Adkins S, Czosnek H, Palukaitis P, Jacquot E, Hohn T, Hohn B, Saunders K, Candresse T, Ahlquist P, Hemenway C, Foster GD, Mol. Plant Pathol. 12, 938-954, 2011. http://dx.doi.org/10.1111/j.1364-3703.2011.00752.x

Scott CL, Hartweck LM, Pérez JJ, Chen D, García JA, Olszewski NE, FEBS Lett. 580, 5829-5835, 2006. http://dx.doi. org/10.1016/j.febslet.2006.09.046

Seo JK, Kang SH, Seo BY, Jung JK, Kim KH, Mol. Plant Pathol. 11, 265-276, 2010. http://dx.doi.org/10.1111/j.13643703.2009.00603.x

Seo JK, Lee SH, Kim KH, MPMI 22, 1151-1159, 2009. http://dx.doi. org/10.1094/MPMI-22-9-1151

Serçe CU, Candresse T, Svanella-Dumas L, Krizbai L, Gazel M, Kadriye Caglayan K, Virus Res. 142, 121-126, 2009. http://dx.doi.org/10.1016/j.virusres.2009.01.022

Sheveleva A, Ivanov P, Prihodko Y, James D, Chirkov S, Plant Dis. 96, 1135-1142, 2012. http://dx.doi.org/10.1094/PDIS12-11-1045-RE

Shi Y, Chen J, Hong X, Chen J, Adams, MJ, Mol. Plant Pathol. 8, 785-790, 2007. http://dx.doi.org/10.1111/j.13643703.2007.00426.x

Shukla DD, Thomas JE, McKern NM, Tracy SL, Ward CW, Arch. Virol. 102, 207-219, 1988. http://dx.doi.org/10.1007/ $\underline{\mathrm{BF} 01310826}$ 
Shukla DD, Tribbick G, Mason TJ, Hewish DR, Geysen HM, Ward CW, PNAS 86, 8192-8196, 1989. http://dx.doi. org/10.1073/pnas.86.21.8192

Sikorskaite S, Vuorinen AL, Rajamäki M-L, Nieminen A, Gaba V, Valkonen JPT, J. Virol. Methods 165, 320-324, 2010. http://dx.doi.org/10.1016/j.jviromet.2010.02.025

Simón-Buela L, Guo HS, García JA, J. Gen. Virol. 78, 2691-2699, 1997.

Szathmáry E, Nadudvári JN, Szabó, L Tobias I, Balazs E, Palkovics L, Arch. Virol. 154, 141-145, 2009. http://dx.doi. org/10.1007/s00705-008-0281-9

Szathmáry E, Palkovics L, Berichte JKI 148, 41, 2009.

Šubr Z, Fomitcheva VW, Kühne T, J. Phytopathol. 148, 461-467, 2000. http://dx.doi.org/10.1046/j.1439-0434.2000.00531.x

Šubr Z, Glasa M, Acta Virol. 43, 259-262, 1999.

Šubr Z, Glasa M, Acta Virol. 52, 75-90, 2008.

Šubr ZW, Glasa M, Acta Fytotech. Zootech. 7, 304-306, 2004a.

Šubr ZW, Kamencayová M, Nováková S, Nagyová A, Nosek J, Glasa M, Arch. Virol. 155, 1151-1155, 2010a. http://dx.doi. org/10.1007/s00705-010-0677-1

Šubr ZW, Kollerová E, Nagyová A, Glasa M, Proc. XVII Czech and Slovak Plant Prot. Conf., Prague, pp. 121-124, 2006.

Šubr ZW, Nagyová A, Glasa M, Julius Kühn Archiv 427, 339-341, 2010 b.

Šubr ZW, Pittnerová S, Glasa M, Eur. Meeting ,04 on Plum Pox, Rogów-Skierniewice, p. 49, 2004a.

Šubr Z, Pittnerová S, Glasa M, Acta Virol. 48, 173-176, $2004 b$.

Šubr ZW, Predajňa L, Glasa M, 22 Int. Conf. on Virus and Other Transmissible Diseases of Fruit Crops, Rome, p. 175, 2012.
Šubr Z, Ryšlavá H, Kollerová E, Acta Virol. 51, 135-138, 2007.

Thompson D, Varga A, De Costa H, Birch C, Glasa M, James D, Plant Dis. 93, 674-674, 2009. http://dx.doi.org/10.1094/ PDIS-93-6-0674A

Urcuqui-Inchima S, Haenni A-L, Bernardi F, Virus Res. 74, 157-175, 2001. http://dx.doi.org/10.1016/S01681702(01)00220-9

Valli A, López-Moya JJ, García JA, J. Gen. Virol. 88, 1016-1028, 2007. http://dx.doi.org/10.1099/vir.0.82402-0

Valli A, Martin-Hernandez AM, Lopez-Moya JJ, Garcia JA, J. Virol. 80, 10055-10063, 2006. http://dx.doi.org/10.1128/ IVI.00985-06

Varrelmann M, Maiss E, J. Gen. Virol. 81, 567-576, 2000.

Varrelmann M, Palkovics L, Maiss E, J. Virol. 74, 7462-7469, 2000. http://dx.doi.org/10.1128/JVI.74.16.7462-7469.2000

Verchot J, Carrington JC, J. Virol. 3668-3674, 1995.

Waltermann A, Maiss E, J. Gen. Virol. 87, 2381-2386. 2006. http:// dx.doi.org/10.1099/vir.0.81873-0

Wei T, Zhang C, Hong J, Xiong R, Kasschau KD, Zhou X, Carrington JC, Wang A, PloS Pathogens 6, 2010

Wetzel T, Candresse T, Ravelonandro M, Delbos M, Dunez J, J. Virol. Methods 33, 355-365, 1991a. http://dx.doi. org/10.1016/0166-0934(91)90035-X

Wetzel T, Candresse T, Ravelonandro M, Delbos RP, Mazyad H, Aboul-Ata AE, Dunez J, J. Gen. Virol. 72, 1741-1746, 1991b. http://dx.doi.org/10.1099/0022-1317-72-7$\underline{1741}$

Yap YK, Duangjit J, Panyim S, Virus Genes 38, 461-467, 2009. http://dx.doi.org/10.1007/s11262-009-0348-Z 